\title{
Autumn electrofishing reduces harm to Ontario (Canada) stream fishes collected during watershed health monitoring
}

\author{
Scott M. Reid ${ }^{1 *}$ and Anita LeBaron ${ }^{1}$ \\ ${ }^{1}$ Aquatic Research and Monitoring Section, Ministry of Natural Resources and Forestry. Trent University - DNA \\ Building, 2140 East Bank Drive, Peterborough ON, K9L 128
}

doi: https://doi.org/10.52201/CEJ18HJVU9134

\begin{abstract}
SUMMARY
Electrofishing surveys provide important information on watershed health, and the status of imperiled and recreationally important stream fishes. Concerns about the harmful effects of electrofishing on the endangered redside dace Clinostomus elongatus have resulted in restrictions on its use in sampling activities in the province of Ontario, Canada. However, the effectiveness of these restrictions is unproven. We undertook a paired sampling gear study in 2018-2019 to test whether an alternate gear (seine nets) or a change in electrofishing timing (autumn rather than summer) reduced harm to stream fishes. The study took place in streams located in the Greater Toronto Area. We found large differences in the frequency and magnitude of sampling-related mortalities between sampling gear and seasons. During individual surveys, electrofishing mortality never exceeded $9 \%$ in the summer or $4 \%$ in the autumn, while seining-related mortality reached $60 \%$ at two stream sites. Overall, autumn electrofishing resulted in mortality rates that were 5.6 and 15 times lower than summer electrofishing and summer seining. These results indicate that survival of Ontario stream fishes can be improved by delaying electrofishing until early autumn.
\end{abstract}

\section{BACKGROUND}

Stream fish sampling by professional and government biologists, and university researchers provides important information on watershed health, and the status and distribution of imperiled and recreationally important species. Summer backpack electrofishing is the standard sampling method for streams in Ontario, Canada (Reid et al. 2009). More broadly across North America, electrofishing is the most commonly deployed method as it is considered to be the most comprehensive and effective method for collecting fishes from streams and rivers (Flotemersch \& Blocksom 2005). However, there are concerns about the harmful effects of electrofishing on fish, especially imperiled species. Harmful effects range from physiological stress, internal bleeding, spinal injuries to direct mortality caused by asphyxiation (Snyder 2003). In Ontario, poor postcapture survival of stream fishes has been noted when sampling occurs on hot summer days (air temperature $>30{ }^{\circ} \mathrm{C}$ ).

A wide spatial overlap in the distribution of imperiled fishes and fish sampling programs exists across southern Ontario. Therefore, there is concern that scientific sampling represents a risk to the recovery of these fishes (Redside Dace Recovery Team 2010). Restrictions on stream sampling activities have been required as part of fish collection permits issued in areas of protected habitat for the endangered redside dace Clinostomus elongatus. The goal of these restrictions is to avoid mortality or harm to fishes. The permitting approach has limited the widespread use of the backpack electrofisher, required different gear types (such as seine nets or underwater cameras) and shifted the timing of electrofishing from summer to autumn. Preferred timing windows have been identified to avoid heat-related stress and increased oxygen demand during fish processing.

Collection permit conditions have been challenged based on the following questions: (1) is there evidence that sampling restrictions reduce harm to stream fishes? (2) are stream fish data collected using other methods equivalent to summer electrofishing data, and therefore easily integrated into long-term watershed health monitoring? and (3) can other gear effectively sample the same breadth of stream habitat conditions as the backpack electrofisher? In this study, we investigated whether an alternate gear type (seine nets) or a change in timing (from summer to autumn) reduces the risk of short-term mortality. Our results address a priority research question identified in the provincial redside dace recovery plan (Redside Dace Recovery Team 2010).

\footnotetext{
*corresponding author email: reid.scott@ontario.ca
} 


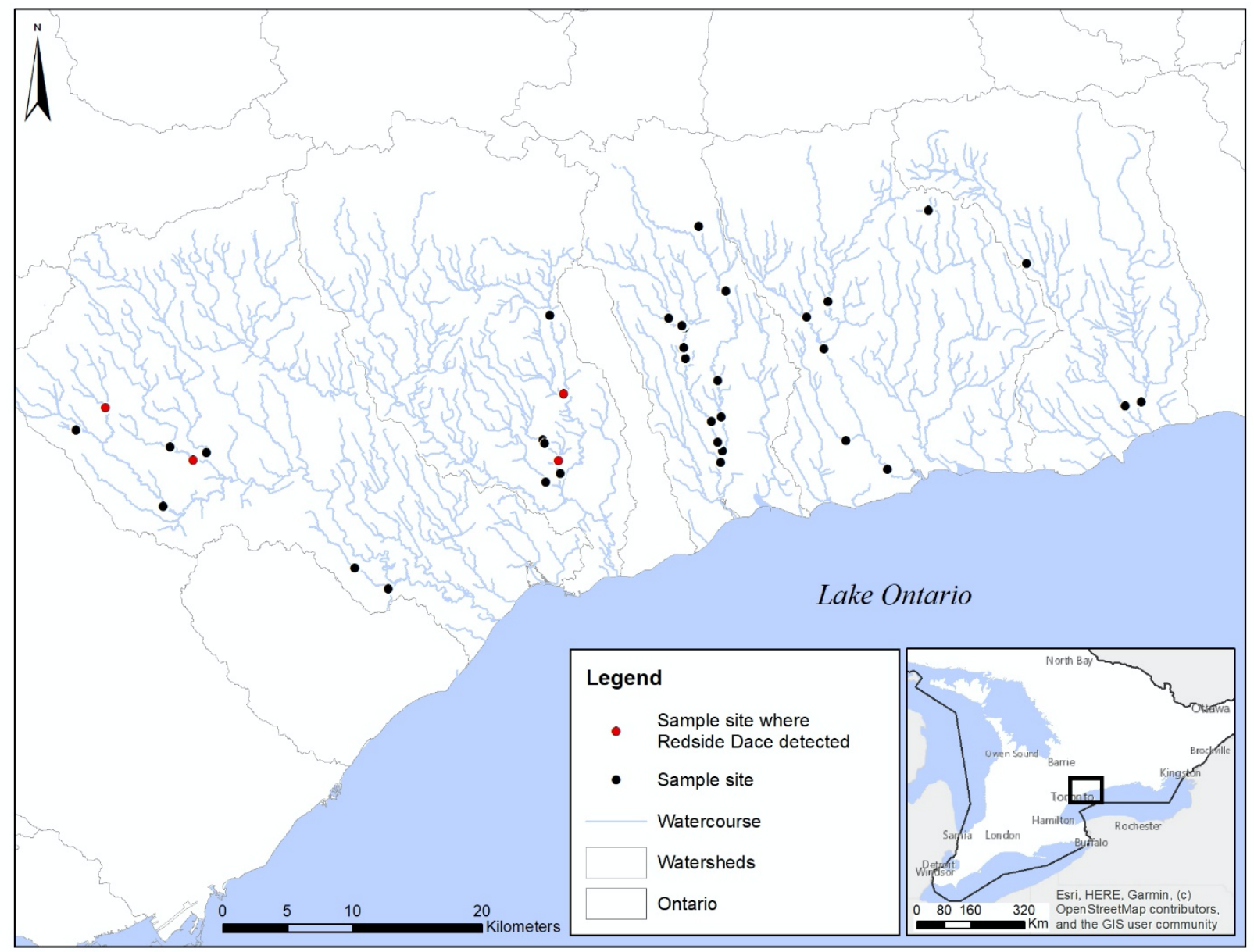

Figure 1. Distribution of Greater Toronto area stream sites $(n=37)$ sampled using backpack electrofisher and seine net in 2018-2019. Location of study area within the Laurentian Great Lakes basin is provided in inset map.

\section{ACTION}

In 2018-2019, we used a paired-sampling approach to collect fishes at 37 stream sites that represent a gradient of watershed health across the eastern region of the Greater Toronto Area $\left(43^{\circ} 52^{\prime} \mathrm{N}\right.$, $78^{\circ} 56^{\prime} \mathrm{W}$, Figure 1). We designed our study to allow for the following comparisons: (1) summer and autumn electrofishing, (2) summer electrofishing and summer seine netting, and (3) summer seine netting and autumn electrofishing. Therefore, summer electrofishing is our baseline (control) dataset.

Randomly selected sites were sampled in Bowmanville Creek, Duffins Creek, Oshawa Creek, Lynde Creek, Rouge River and Soper Creek. These locations are long-term monitoring sites that were selected using a stratified random design where watershed, stream order and landuse type are strata. Average wetted channel widths of stream sites ranged from 1.2-15.2 m (median $=5.0 \mathrm{~m})$. Site lengths were scaled based on channel width, ranging from 41-87 m (Stanfield 2017). Summer sampling occurred between 28 June and 18 September. Water temperatures ranged from $13-27^{\circ} \mathrm{C}\left(\right.$ median $\left.=20{ }^{\circ} \mathrm{C}\right)$, and maximum daily air temperatures from $23-32^{\circ} \mathrm{C}$ (median $\left.=27^{\circ} \mathrm{C}\right)$. Autumn sampling occurred between 9 and 21 October. Water temperatures ranged from $5-19{ }^{\circ} \mathrm{C}\left(\right.$ median $\left.=10^{\circ} \mathrm{C}\right)$ and maximum daily air temperatures from $12-26^{\circ} \mathrm{C}($ median $=15$ $\left.{ }^{\circ} \mathrm{C}\right)$.

During the summer, we sampled sites using a backpack electrofisher (Smith-Root Model 12-B), with pulsed direct current (DC) output set from 100 to $300 \mathrm{~V}$. The electrofisher creates an electrical field that attracts and/or stuns nearby fishes. The effectiveness of electrofishing is dependent on electrical field intensity, duration of exposure and fish size and shape (Snyder 2003). A single-pass method with one or two netters was used to collect 
fishes (Figure 2, Reid et al. 2009, Stanfield 2017) from all riffle, run and pool habitats. Median sampling intensity was 3.4 seconds per $\mathrm{m}^{2}$. In the autumn, we resampled the same habitats at each of the sites using the same single-pass electrofishing method. Median sampling intensity was 4.0 seconds / $\mathrm{m}^{2}$.
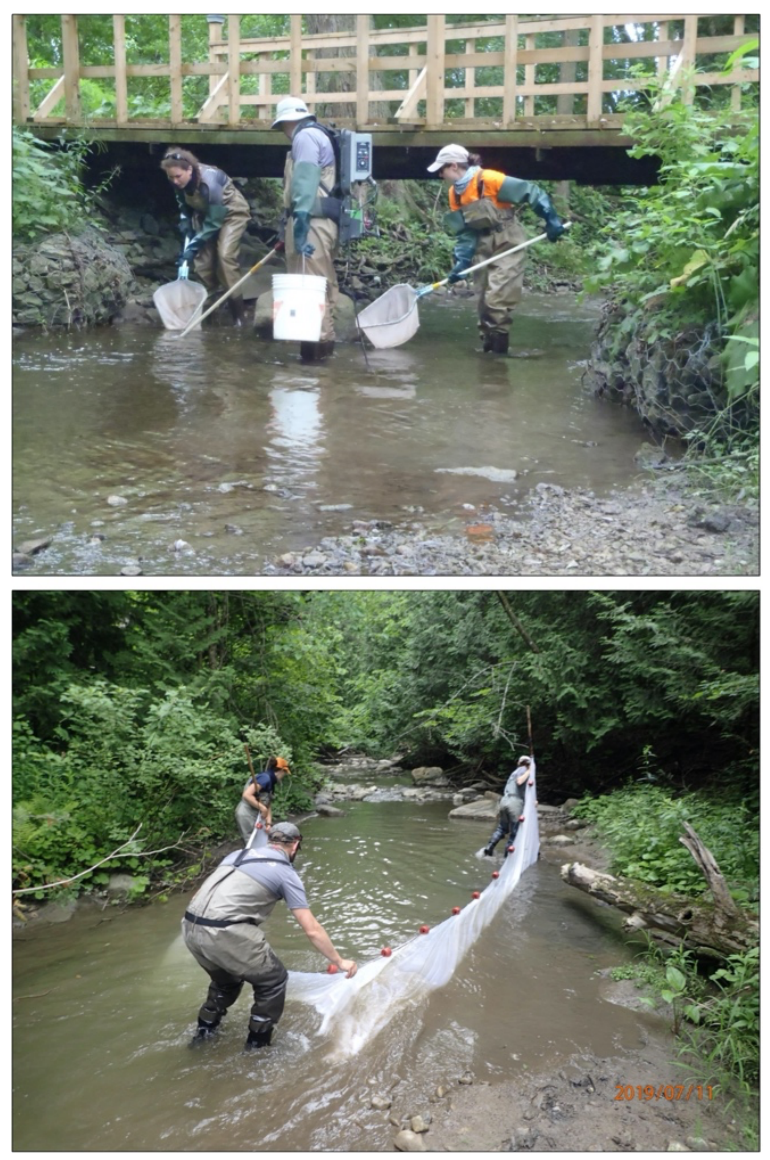

Figure 2. Field crews sampling stream fishes with backpack electrofisher (top image) and seine net (bottom image). Photo credits: K. Vardy (top) and A. LeBaron (bottom).

After summer electrofishing, we resampled the same area with a bag seine (dimensions: $9.1 \mathrm{~m}$ long and $1.2 \mathrm{~m}$ deep with a $1.2 \mathrm{~m} \times 1.2 \mathrm{~m} \times 1.2 \mathrm{~m}$ bag, 3.2 $\mathrm{mm}$ diameter mesh). The bag seine is an active gear where fishes are herded into the bag by pulling the net through the water (Bonar et al. 2009). At our study sites, two people pulled the net upstream while a third person ensured the bag opened and assisted with untangling the net from obstructions (Figure 2). Seine hauls were completed across the entire site. A minimum of one week separated electrofishing and seine netting. The time interval between electrofishing and seining was sufficiently long (>1 day) to allow individuals to redistribute throughout the site before resampling and avoid behavioural changes that negatively affect subsequent catchability (Mesa and Schreck 1989).

We held fishes in buckets of clean water (or flowthrough bins) after capture. All individuals were identified to species, counted, and batch-weighed before being released. When large numbers of fishes were captured, we used multiple buckets to prevent overcrowding and replaced water periodically $(\sim 10$ minute interval).

Our mortality counts were based on the number of dead or moribund individuals observed in the processing bins and along the streambed. Imperfect detection of sampling-related mortalities and longerterm mortality related to injuries or handling stress were not assessed. Future estimates could be improved by installing a block-net at the downstream end of the site to capture moribund individuals floating downstream, or by holding captured individuals in enclosures over several days to monitor survival (e.g. Cooke et al. 1998). Stream sampling was not done by the same individuals at each site. Therefore, some variability in mortality counts could be due to differences in experience collecting and handling fishes.

Sampling was done under Species at Risk Act Permit Number 19-PCAA-00023 and Animal Use Protocol AUP-154, approved by the Ministry of Natural Resources and Forestry Animal Care Committee (operated under approval of the Canadian Council on Animal Care).

We used the Pearson correlation coefficient to assess between-method agreement (combinations of sampling gear and seasons) for catch statistics (numbers of individuals and species). The nonparametric Friedman Test and subsequent pairwise Wilcoxon tests were used to test for differences in mortality rates ( $\%$ of individuals captured). Statistical tests were done using the software PAST version 4.01 (Hammer et al., 2001).

\section{CONSEQUENCES}

We captured 22,165 individuals that represented a mix of forty cold-, cool- and warm-water species. Redside dace (49 individuals) was captured with both sampling gear types from four stream sites. Ten recreationally important species were also captured during sampling: Atlantic salmon Salmo salar, brook trout Salvelinus fontinalis, brown trout Salmo trutta, Chinook salmon Oncorhynchus tshawytscha, coho salmon Oncorhynchus kisutch, largemouth bass Micropterus salmoides, northern pike Esox lucius, rainbow trout Oncorhynchus mykiss, smallmouth bass Micropterus dolomieu and yellow perch Perca flavescens. There were moderate differences in 
average numbers of individuals caught by electrofisher and seine net (Figure 3). The total number of individuals in summer and autumn electrofishing catches at each site were similar and strongly correlated (Pearson correlation: $\mathrm{r}=0.73, \mathrm{p}<$ $0.001)$. The number of species detected at each were similar (Figure 3) and strongly correlated among sampling gears and seasons (summer vs autumn electrofishing: $r=0.74$, summer electrofishing vs seine: $r=0.74$, summer seine vs autumn electrofishing $r=0.70 ; p<0.001$ for all comparisons).
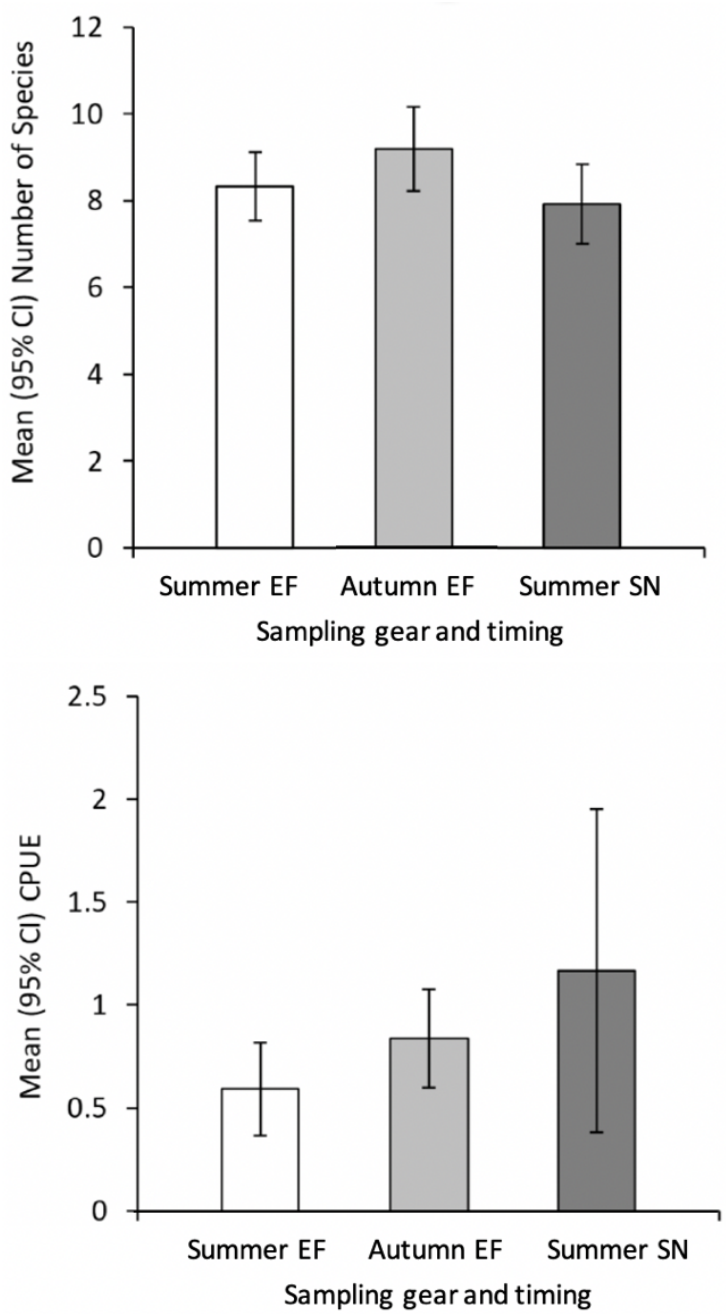

Figure 3. Comparison of number of species (top graph) and catch-per-unit-effort (bottom graph) detected from 37 stream sites sampled by backpack electrofisher (EF) and seine (SN) in 2018-2019. Catch-per-unit-effort (CPUE) is number of individuals per $\mathrm{m}^{2}$ sampled.
We detected sampling-related mortalities during $50 \%$ of autumn electrofishing, $64 \%$ of summer electrofishing, and $86 \%$ of summer seining surveys. Mortality rates differed among gears used and seasons sampled (Table 1 and Figure 4; Friedman Test: chi-square $=22.4, \mathrm{p}<0.001$; pairwise Wilcoxon tests: $\mathrm{p}<0.002$ ). During individual surveys, electrofishing mortality never exceeded 9\% in the summer or $4 \%$ in the autumn. Seining-related mortality reached $60 \%$ at two stream sites. Compared to summer electrofishing, average autumn electrofishing mortality rates were 5.6 times lower, and the maximum was 2.5 times lower. Compared to summer seining, average autumn electrofishing mortality rates were 15 times lower, and the maximum was 20 times lower.

We found small-bodied benthic species such as blacknose dace Rhinichthys atratulus, longnose dace Rhinichthys cataractae and rainbow darter Etheostoma caeruleum to be most vulnerable to electrofishing harm (Table 1). Seining-related mortalities were most associated with common shiner Luxilus cornutus and young-of-year cyprinids (unidentified minnow species). All redside dace survived capture and handling.

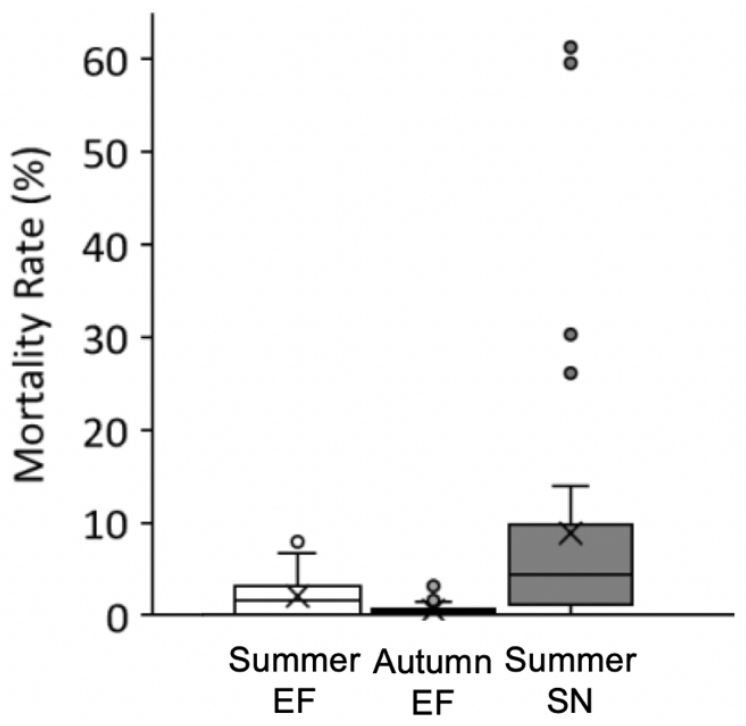

Figure 4. Box-whisker plot comparison of mortality rates associated with sampling of 37 stream sites by backpack electrofisher (EF) and seine (SN) in 20182019. Mortality rate was calculated using the total number of individuals captured at a site. 
Table 1. Among-species comparison of fish mortalities resulting from stream sampling by electrofisher (EF) and seine (SN). Percent composition of the total number of mortalities recorded for each gear type and season are presented. Number of sites sampled was 37.

\begin{tabular}{lccc}
\hline Species & Summer EF & Autumn EF & Summer SN \\
\hline Atlantic salmon & & 1.7 & \\
blacknose dace & 19.8 & 15.5 & 2.8 \\
bluntnose minnow & 2.1 & 8.6 & 1.4 \\
common shiner & 2.1 & 1.7 & 46.4 \\
creek chub & 14.6 & 5.2 & 3.7 \\
fathead minnow & 13.5 & 1.7 & $<1$ \\
johnny darter & & 1.7 & 11.0 \\
longnose dace & 13.5 & 37.9 & $<1$ \\
mottled sculpin & 1.0 & 3.4 & \\
rainbow darter & 10.4 & 6.9 & 1.6 \\
rainbow trout & 4.2 & 6.9 & $<1$ \\
rosyface shiner & & & $<1$ \\
round goby & & 3.4 & $<1$ \\
smallmouth bass & & & $<1$ \\
brook stickleback & 18.8 & 5.2 & $<1$ \\
white sucker & & & 5.1 \\
unknown minnow & 96 & 56 & 2211 \\
\hline Total number of mortalities & 1.7 & 0.3 & 4.4 \\
Median mortality rate & & 3.2 & 61.2 \\
Maximum mortality rate & 8.2 & & \\
\hline
\end{tabular}

${ }^{\text {a }}$ mortality rate calculated as a percentage of all individuals captured at a site.

\section{DISCUSSION}

Controlled experiments have shown that risk of electrofishing harm to stream fishes can be reduced by adjusting output settings and limiting the time individuals are exposed to the electrical field (Snyder 2003). Our field study demonstrates that survival of Ontario stream fishes can be further improved by delaying electrofishing till early autumn. Lower air and water temperatures in the autumn are presumably beneficial, as metabolism is reduced and behavioural responses to the electrical field are slowed (Snyder 2003). High levels of harm to redside dace from electrofishing have been noted by some researchers (Poos et al. 2012). However, we did not observe any negative impacts to redside dace as a result of sampling.

Despite its widespread use and known risk to stream fishes, there is little research comparing backpack electrofishing injury to other standard gears, such as the seine netting. Overall, injuries incurred by seined fishes are poorly documented (Poos et al. 2007). Seines capture fishes in bulk and often in much greater numbers than electrofishing. Therefore, the average time each fish is held in buckets is longer as sample processing times are greater. Respiration by a large biomass of fishes can rapidly deplete available oxygen, especially when water temperatures elevated. Our mortality assessment was strongly influenced by two sampling events where the collection of very large numbers of individuals $(>1700)$ during seine netting coincided with the highest mortality rates $(\sim 60 \%)$. We also found harm can occur when cobbles or other large objects are collected in the bag of the seine, or when slender-bodied fishes were stuck in the mesh.

We found the seine net was not as widely suitable for stream sampling as the electrofisher as it was easily snagged on boulders and woody debris and ineffective at collecting fishes from undercut banks. Therefore, as noted by Poos et al. (2007), it may be better to develop electrofishing protocols that are less injurious to imperiled fishes than to switch to seine netting. For example, Cooke et al. (1998) found 3second spot electrofishing avoided injuries to greenside darter (Etheostoma blennoides) when 
compared to the traditional sweep-sampling technique. Our study supports a shift in electrofishing timing in stream reaches occupied by redside dace. Although the focus of our study was the collection of fish community data, non-invasive alternatives such as underwater cameras and environmental DNA have recently been validated for the detection of redside dace (Serrao et al. 2018, Castañeda et al. 2020).

In Ontario, stream fish community attributes used as indicators of watershed health include species richness, indicator species, trophic guilds, fish abundance and incidence of disease (Steedman 1988). Our study did not assess whether data collected by different gear types or in different seasons provides comparable information for monitoring; although strong correlations between abundance and species richness data collected by summer and autumn electrofishing are promising.

\section{ACKNOWLEDGEMENTS}

Research was supported by Fisheries and Oceans Canada and Ontario Ministry of Natural Resources and Forestry species at risk program funds. We would like to acknowledge the efforts of Central Lake Ontario Conservation Authority and Toronto and Region Conservation Authority staff, as well as the many Ontario Ministry of Natural Resources and Forestry staff that helped with fish sampling.

\section{REFERENCES}

Bonar, S. A., Hubert, W. A. \& Willis, D. W. (2009). Standard methods for sampling North American Fishes. American Fisheries Society, Bethesda, Maryland.

Castañeda R. A, Weyl O. L. F \& Mandrak N. E. (2020) Using occupancy models to assess the effectiveness of underwater cameras to detect rare stream fishes. Aquatic Conservation: Marine \& Freshwater Ecosystems, 30, 565- 576. https://doi.org/10.1002/aqc.3254

Cooke S. J., Bunt C. M. \& McKinley S. R. (1998) Injury and short term mortality of benthic stream fishes - a comparison of collection techniques. Hydrobiologia, 379, 207-211. https://doi.org/10.1023/A:1003288117978

Flotemersch J. E. \& Blocksom K. A. (2005) Electrofishing in boatable rivers: does sampling design affect bioassessment metrics?

Environmental Monitoring \& Assessment, 102, 263-83. https://doi.org/10.1007/s10661-0056026-2
Hammer Ø., Harper D. A. T. \& Ryan P. D. (2001) PAST: paleontological statistics software package for education and data analysis. Palaeontologia Electronica, 4, 1-9.

Mesa, M. G. \& Schreck, C. B. (1989) Electrofishing mark-recapture and depletion methodologies evoke behavioural and physiological changes in cutthroat trout. Transactions of the American Fisheries Society, 118, 644-658. https://doi.org/10.1577/15488659(1989)118<0644:EMADME >2.3.CO;2

Poos M., Lawrie D., Tu C., Jackson D.A. \& Mandrak N. E. (2012) Estimating local and regional population sizes for an endangered minnow, redside dace (Clinostomus elongatus), in Canada. Aquatic Conservation: Marine and Freshwater Ecosystems, 22, 47-

57. https://doi.org/10.1002/aqc. 1235

Poos M. S., Mandrak N. E., \& McLaughlin R. L. (2007) The effectiveness of two common sampling methods for sampling imperiled freshwater fishes. Journal of Fish Biology, 70, 691-708. https://doi.org/10.1111/j.10958649.2007.01349.x

Redside Dace Recovery Team (2010) Recovery Strategy for Redside Dace (Clinostomus elongatus) in Ontario. Ontario Recovery Strategy Series. Prepared for the Ontario Ministry of Natural Resources, Peterborough, Ontario.

Reid S. M., Yunker G. \& Jones N. (2009) Evaluation of single-pass electrofishing for stream fish community monitoring. Fisheries Management \& Ecology, 16, 1-9. https://doi.org/10.1111/j.13652400.2008.00608.x

Serrao N, Reid S. M. \& Wilson C. C. (2018) Using Receiver Operator Characteristic to identify detection thresholds for environmental DNA. Conservation Genetics Resources, 10, 555-562. https://doi.org/10.1007/s12686-017-0817-y

Snyder D. E. (2003) Invited overview: Conclusions from a review of electrofishing and its harmful effects on fish. Reviews in Fish Biology \& Fisheries, 13, 445-453. https://doi.org/10.1007/s11160-004-1095-9

Stanfield, L. (2017) Ontario Stream Assessment Protocol. Version 10. Ontario Ministry of Natural Resources.

Steedman R. J. (1988) Modification and assessment of an Index of Biotic Integrity to quantify stream quality in southern Ontario. Canadian Journal of Fisheries \& Aquatic Sciences, 45, 492-501. https://doi.org/10.1139/f88-059

The Conservation Evidence Journal is an open access online journal devoted to publishing the evidence on the effectiveness of management interventions. The other papers from The Conservation Evidence Journal are available from www.conservationevidencejournal.com. The pdf is free to circulate or add to other websites and is licensed under the Creative Commons Attribution 4.0 International License http://creativecommons.org/licenses/by/4.0/. Under this licence, authors retain ownership of the copyright for 